\section{NATURE OF THE HAIRY CELL}

SIR,-We read with interest the report by Dr Catovsky and his associates (Feb. 22, p. 462) supporting our scanningelectron-microscopy (S.E.M.) findings ${ }^{1}$ that in hairy-cell leukæmia (H.C.L.) hairy cells in the spleen resemble B lymphocytes. They also report that hairy cells from the peripheral blood in H.C.L. have the S.E.M. appearance of monocytes. We have observed hairy cells from the blood of two patients with H.C.L. and found cells with surface characteristics similar to those described by Catovsky and his colleagues. These cells had ridges and ruffles (fig. 1), thus resembling monocytes and histiocytes. ${ }^{2}$ Other cells had both villous processes and ruffles (fig. 2), thus having features of both B lymphocytes and monocytes. Such cells resembled the " hybrid" cells in H.C.L. reported by Roath and Newell (Feb. 1, p. 283).

We also agree with the suggestion of Catovsky et al. that a number of factors may influence the surface morphology of hairy cells and other lymphocytes. Among these factors are the environment in which the cells are found, the phase of the cell cycle, and the different methods used in obtaining the cells from either blood or tissue. ${ }^{3-5}$ Such

1. Schnitzer, B., Hammack, W. J. Lancet, 1974, ii, 649

2. Polliack, A., Braylan, R., Golomb, H. ibid. p. 1013.

3. Lin, P. S., Cooper, A. G., Wortis, H. H. New Engl. F. Med. 1974, $289,548$.

4. Linthicum, D. S., Sell, S. ibid. 1974, 290, 1327.

5. Sullivan, A. K., Adams, L. S., Silke, I., Jerry, L. M. ibid. p. 689.

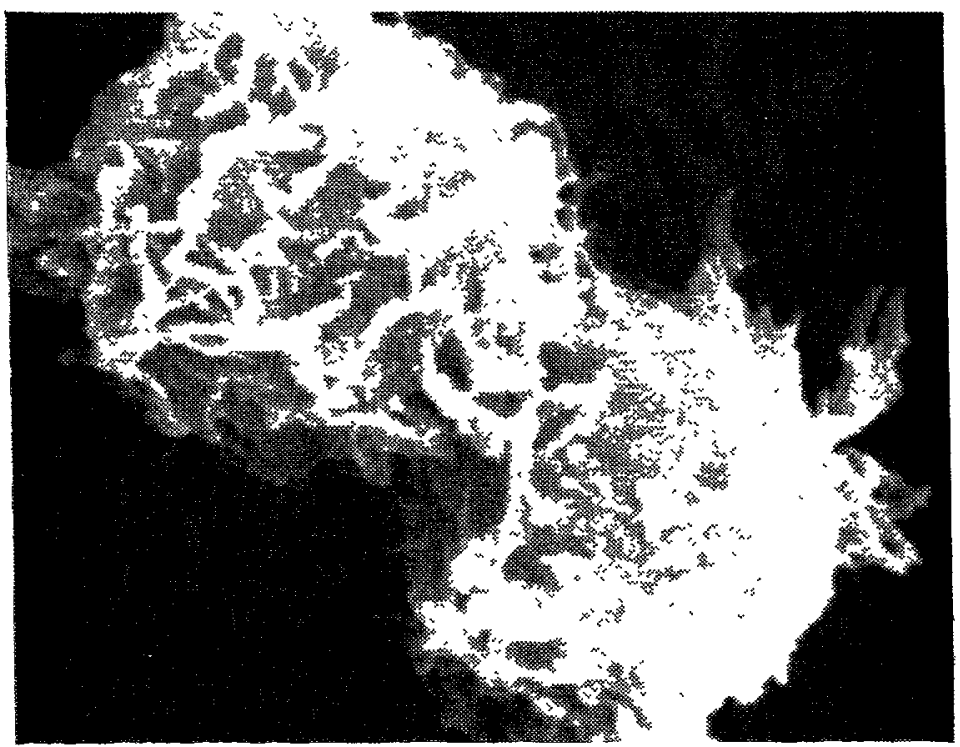

Fig. 1-Hairy cell (peripheral blood).

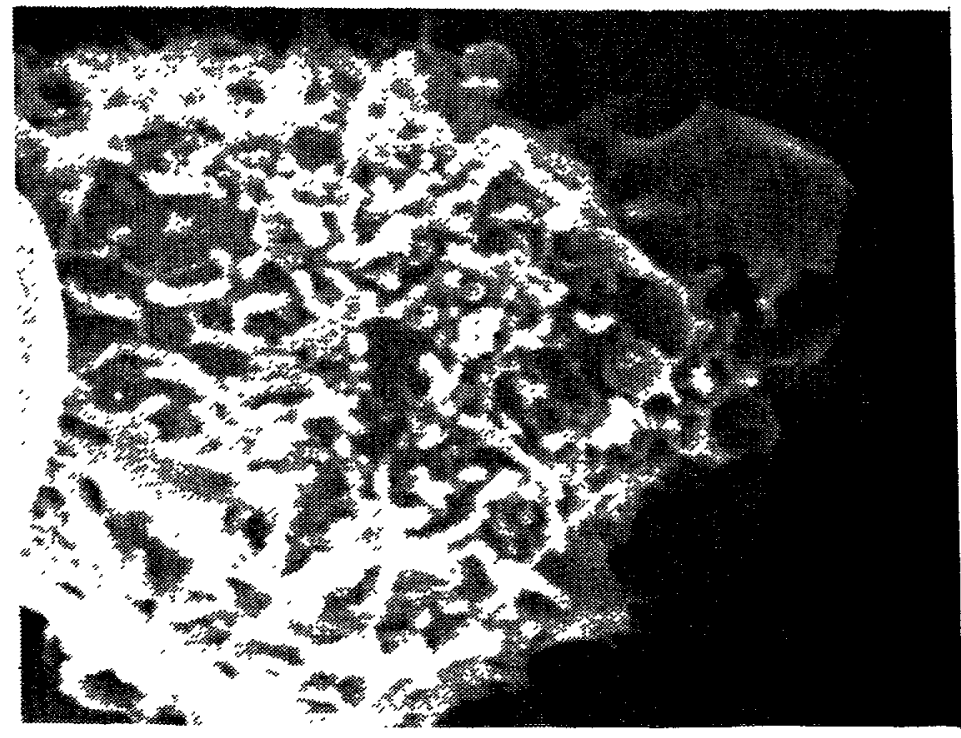

Fig. 2-Hairy cell (peripheral blood).

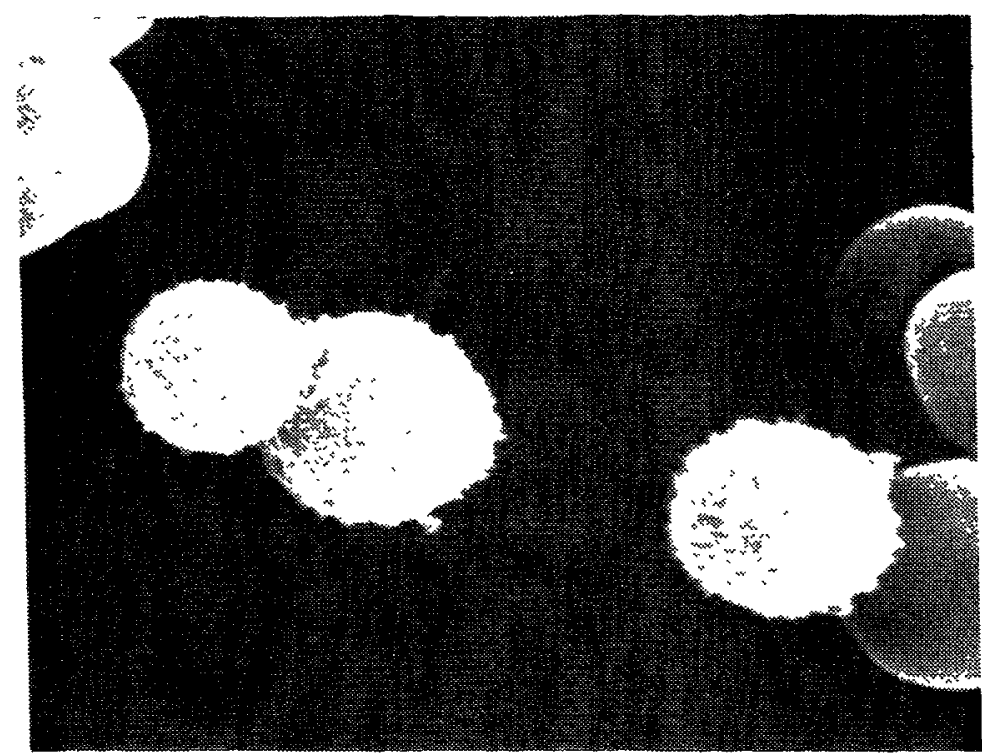

Fig. 3-Lymphocytes (peripheral blood).

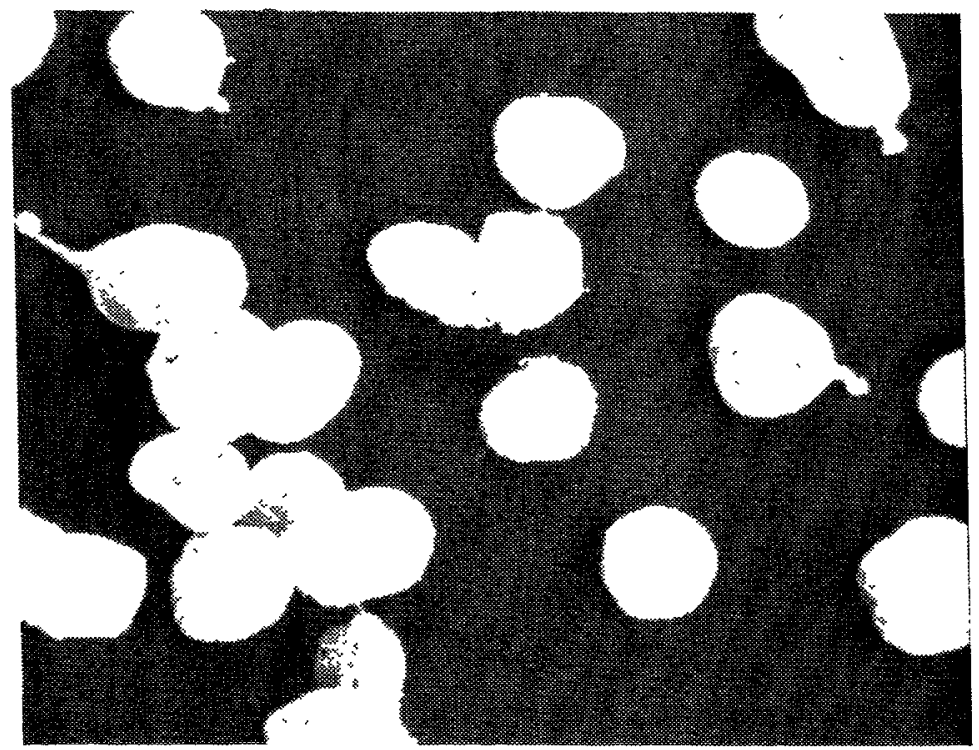

Fig. 4-Lymphocytes (lymph-node).

differences in surface morphology were evident in a case of chronic lymphocytic leukæmia (C.I.L.) in which we observed by S.E.M. lymphocytes from both the peripheral blood and a biopsied lymph-node. The normal architecture of this node was completely replaced by a diffuse proliferation of mature-looking lymphocytes, characteristic of lymph-node involvement by c.L.L. By transmission electron microscopy, the lymphocytes from the blood and the lymph-node appeared identical. By s.E.M., however, most of the lymphocytes from the blood had the villous surface characteristics of B lymphocytes (fig. 3), while almost all the lymphocytes from the lymph-node had a relatively smooth surface characteristic of $T$ cells (fig. 4).

As other investigators ${ }^{4-7}$ have pointed out, it is hazardous to attempt to classify lymphocytes as $B$ or $T$ cells on the basis of surface morphology alone. Additional investigations combining immunological, functional, and S.E.M. studies are needed to clarify the nature of normal lymphocytes and of lymphocytes in lymphoproliferative disorders.

Department of Pathology,

University of Michigan, Ann Arbor,

B. SCHNITZER

Michigan 48104, U.S.A.

\section{L. MEAD.}

6. Galey, F. R., Prehal, J. T., Amromin, G. D., Jhurani, Y. ibid. p. 690.

7. Lin, P. S., Cooper, A. G., Wortis, H. ibid. 